
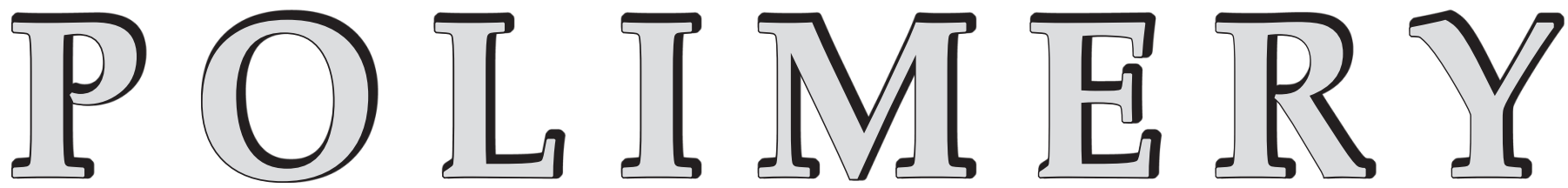

\title{
Composites based on conductive polymer with carbon nanotubes in DMMP gas sensors - an overview
}

\author{
N.M. Nurazzi ${ }^{1)}$ (ORCID ID: 0000-0001-7697-0511), M.M. Harussani ${ }^{1)}$, N.D. Siti Zulaikha ${ }^{1)}$ (0000-0001-6706-7216),

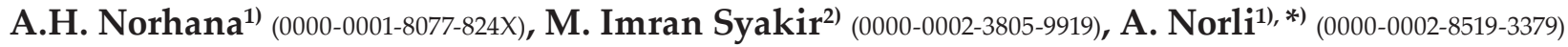

DOI: dx.doi.org/10.14314/polimery.2021.2.1

\begin{abstract}
A number of recent terrorist attacks make it clear that rapid response, high sensitivity and stability are essential in the development of chemical sensors for the detection of chemical warfare agents. Nerve agent sarin [2-(fluoro-methyl-phosphoryl) oxypropane] is an organophosphate (OP) compound that is recognized as one of the most toxic chemical warfare agents. Considering sarin's high toxicity, being odorless and colorless, dimethyl methylphosphonate (DMMP) is widely used as its simulant in the laboratory because of its similar chemical structure and much lower toxicity. Thus, this review serves to introduce the development of a variety of fabricated chemical sensors as potential sensing materials for the detection of DMMP in recent years. Furthermore, the research and application of carbon nanotubes in DMMP polymer sensors, their sensitivity and limitation are highlighted. For sorption-based sensors, active materials play crucial roles in improving the integral performances of sensors. The novel active materials providing hydrogen-bonds between the polymers and carbon nanotubes are the main focus in this review.
\end{abstract}

Keywords: carbon nanotubes, DMMP, chemical sensor, conductive polymer.

\section{Kompozyty na osnowie polimeru przewodzącego z udziałem nanorurek węglowych w czujnikach gazu DMMP - przegląd literatury}

Streszczenie: Przeprowadzone w ostatnich latach liczne ataki terrorystyczne jasno wskazują, że w wypadku czujników do wykrywania chemicznych środków bojowych są niezbędne: ich wysoka czułość, szybka reakcja i stabilność. Środek paralityczno-konwulsyjny sarin (2-fluorometylofosforylooksypropan) to związek fosforoorganiczny (OP) uznawany za jeden z najbardziej toksycznych dostępnych chemicznych środków bojowych. Ze względu na to, że jest on bezwonny, bezbarwny, a ponadto bardzo toksyczny, w badaniach laboratoryjnych szeroko stosuje się jego symulator - metylofosfonian dimetylu (DMMP), o podobnej strukturze chemicznej i znacznie mniejszej toksyczności. W artykule przedstawiono rozwój technologii czujników chemicznych do wykrywania gazu DMMP. Omówiono badania dotyczące wykorzystania kompozytów polimerowych z udziałem nanorurek węglowych w czujnikach gazu DMMP. W wypadku czujników, w których wykorzystuje się zjawisko sorpcji, kluczową rolę w poprawie ich wydajności odgrywają materiały aktywne. W niniejszym przeglądzie skupiono się na

\footnotetext{
1) National Defence University of Malaysia, Centre for Defence Foundation Studies, Kem Sungai Besi, 57000 Kuala Lumpur, Malaysia.

2) Universiti Teknikal Malaysia Melaka, Faculty of Mechanical Engineering, Hang Tuah Jaya, 76100 Durian Tunggal, Melaka, Malaysia.

*) Author for correspondence: norli.abdullah@upnm.edu.my
} 
nowatorskich materiałach aktywnych, w których występują wiązania wodorowe między polimerem a nanorurkami węglowymi.

Słowa kluczowe: nanorurki węglowe, DMMP, czujnik chemiczny, polimer przewodzący.

Organophosphate compounds (OPs) are significant environmental and food chain pollutants because they are intensively used as pesticides [1]. Several highly toxic OPs have been developed and stored as chemical warfare agents (CWA). CWA can be divided into several categories such as nerve (paralytic-convulsive) agents, blistering agents, asphyxiants, blood agents and out of category hydrofluoric acid. These categories are classified according to their chemical structure and their mechanism of action and impact on the human body. Among the many toxic chemical agents present, OP compounds, the typical members of nerve agents, are recognized as one of the most toxic warfare agents. There are two main classes of nerve agents, the G-series and V-series [2]. The first OP insecticide was created in the mid-1800s but was not widely used until after World War II. Organophosphates are used as insecticides and nerve agents as weapons.

Unfortunately, these hazardous nerve agents have been used as a weapon to kill a large number of people, terrorize people and countries. Nerve agents such as sarin, tabun and soman are G-type nerve agents, and EA-3148, VE, VG, VM, VP, VR, VS, VX are V-type series that are dangerous due to their volatility at low temperature, as well as their colorless, high toxicity and odorless characteristics [3, 4]. Toxic concentrations of these compounds are expressed in comparison to carbon monoxide, which has an acute exposure guideline level-3 (AEGL-3) or lethal inhalation concentration value of $1900 \mathrm{mg} / \mathrm{m}^{3}$ for a $10 \mathrm{~min}$ exposure. The corresponding value for sarin is $0.38 \mathrm{mg} / \mathrm{m}^{3}$, which is 5000 times lower than that of carbon monoxide (CO) [5].

The symptoms of sudden poisoning by OPs start during or after exposure, depending on the contact with the poison. The symptoms include headache, dizziness, diarrhea, nausea and vomiting, salivation, watery eyes. Severe symptoms include seizures, slow pulse, difficulty breathing, and coma that finally leads to sudden death. Long after exposure, people can also develop nervous system problems such as muscle weakness and numbness and tingling of the hands and feet (neuropathy). Long-term exposure to OPs leads to confusion, anxiety, and loss of memory and appetite, disorientation, depression, and personality changes. Nerve agents exert their effects by inhibiting the enzyme acetylcholinesterase (AChE), leading to an excessive accumulation of the neuro transmitter acetylcholine (ACh) at cholinergic synapses. Enzyme inhibition is both a rapid and irreversible process, which makes nerve agents highly toxic and extremely dangerous [6]. These toxic agents directly attack the nervous system and inhibit the enzyme cholinesterase by creating covalent bonds with a serine residue at the enzyme's active site and then cause rapid inhibition of serine proteases in the nervous system. The inhibition of acetylcholinesterase severely influences the human body by reducing the breakdown of acetylcholine, which will lead to death after a few seconds [7]. One prominent example in this respect is the gas sarin, a nerve agent that causes death by suffocation within 1 to $10 \mathrm{~min}$ of exposure at concentrations above 60 ppb (parts-per billion) [8].

Scheme A shows the mechanism of action acetylation and deacetylation of AChE. In general, enzymesubstrate complex is formed by the electrostatic attraction between an anionic site (the negative charge of the anionic site is due to the carboxylate anion of aspartic or glutamic acid) on the enzyme AChE and the positively charged nitrogen atom of the ACh on the human enzyme $[9,10]$. Acetylation of a serine hydroxyl $(\mathrm{OH})$ in the esteric site of the enzyme AChE [Scheme A(i)] is catalyzed by the basic imidazole moiety of histidine, which interacts with the carboxyl group of glutamate (serine, histidine, and glutamate are part of a catalytic triad of esteric site of the enzyme AChE), leading to an acetylated enzyme. Whereas, deacetylation then takes place, and the free enzyme is released together with choline and acetic acid, as an end product [Scheme A(ii)].

The mechanism of OPs or nerve agent action is similar to the initial step of ACh hydrolysis. OPs penetrate through the structure of AChE to the catalytic active site. Nucleophilic serine attacks the phosphorus atom, forming a bipyramidal transition state, which release halide ion and the formation of phosphylated serine (Scheme B). Later, histidine residue is unable to fulfil its water activation function, and spontaneous hydrolysis is therefore extremely slow, varying from minutes to hours. This hydrolysis failure is explained by the formation of inappropriate conformation of OPs or shielding from the histidine water molecule of OP conjugate. Time-dependent intramolecular response appears in spontaneous hydrolysis of OP conjugates. This process involves the treatment of alkoxy substituent phosphorous atoms produced by phosphonate adducts denoted as "aged" conjugate. The aged conjugate forms a salt bridge with the protoncatalytic histidine resulting in a strong stabilization. This such aged AChE is resistant to hydrolysis and reactivation by antidotes and medical devices. That leads to any serious circumstances [10,11].

As the acetylcholine builds up in our bodies, it leads to the cholinergic effect and death. The affected people are killed by the accumulation of their own normal neurotransmitter telling their own nerves to do the things they normally do, just in excess. However, with nothing to break down the neurotransmitter, it continues to bind to the receptors, triggering them to repeatedly respond. 


\section{i) Acetylation of AChE}

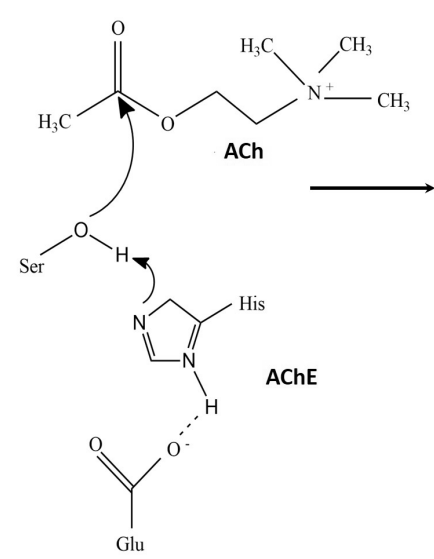<smiles>CN1C[NH+](CCCOCCC[N+](C)(C)C)CC1(C)O</smiles>

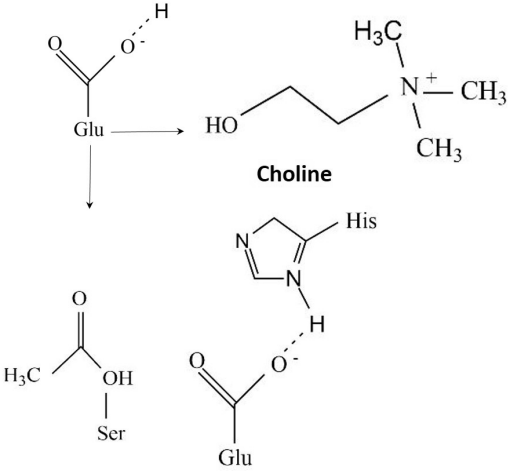

Acetylated AChE

ii) Deacetylation of AChE
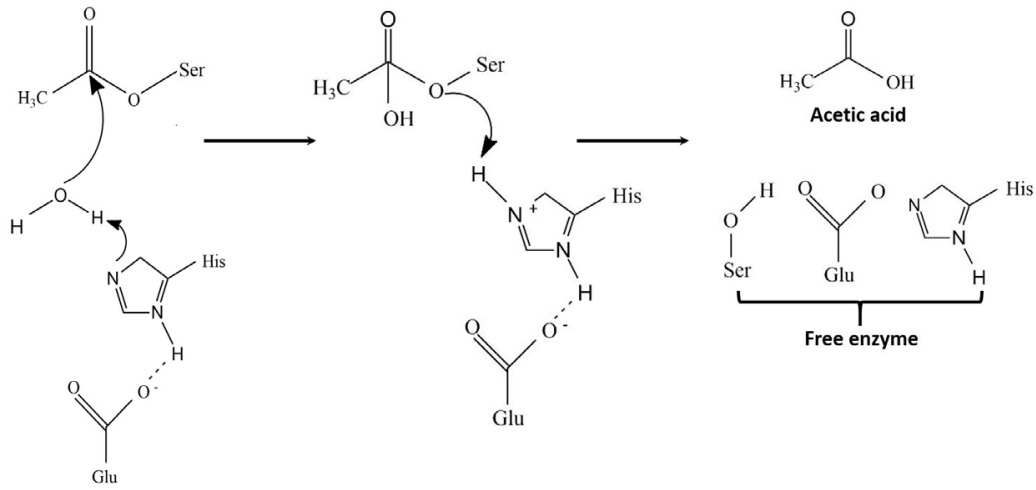

Scheme A. Mechanism of action of acetylation and deacetylation of human enzyme

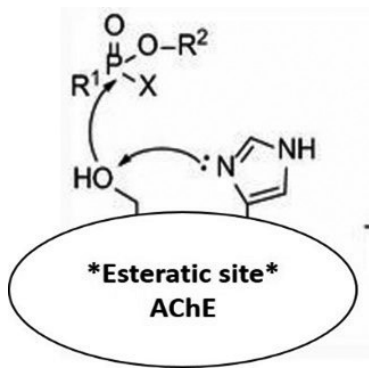

a)

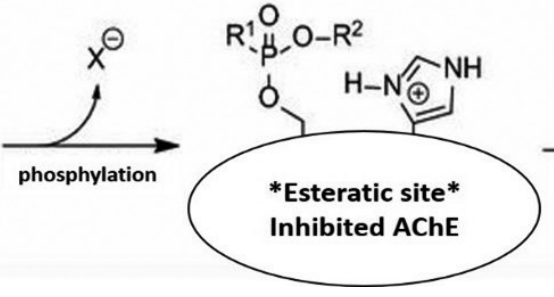

b)

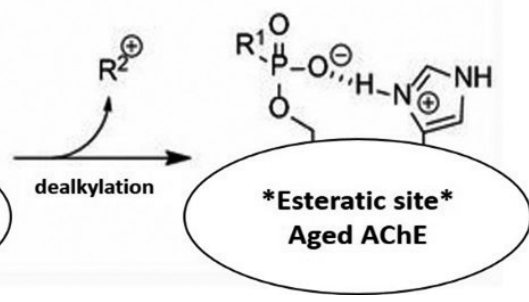

c)

Scheme B. Inhibition of AChE by nerve agent, and aging of AChE mechanism of action

Finally, overstimulation of muscles occurs leading to the shutdown of the respiratory system and progression to convulsions, paralysis, and death [12]. We are killed by the accumulation of our own normal neurotransmitter that telling our own nerves to do the normal things they normally do, just in excess. Besides that, aging rates are varying among the several OPs, for tabun, the half-life for the aging of the phosphyl-AChE is about 19 hours, for sarin is about 3 hours, for cyclosarin, 7 hours, for VX 48 hours, and for soman only 2 minutes. The extraordinarily fast aging rate of soman and other OPs became a great challenge for the treatment of victims of this agent, since it demands a nearly detection and immediate administration of the currently used antidotes, limiting their efficacy [13].

The large scale repeated use of nerve agents during the Iran-Iraq war in the 1980s against civilians by Iraqi troops, and during terrorist attacks by the Aum Shinrikyo sect in Japan [14], emphasize the constant threat and urgent 
T a b l e 1. An overview of CWA, their method of exposure and the clinical symptoms

\begin{tabular}{|c|c|c|c|}
\hline CWA type & Chemical agents & Method of exposure & Clinical signs \\
\hline Nerve agents & $\begin{array}{l}\text { G-agents (sarin, cyclosarin, } \\
\text { tabun, soman) } \\
\text { V-agents (EA-3148, VE, VG, } \\
\text { VM, VP, VR, VS, VX) }\end{array}$ & Inhalation & $\begin{array}{l}\text { Vomiting and diarrhea, } \\
\text { miotic pupils, bradycardia, } \\
\text { bronchorrhea, muscle spasms, } \\
\text { weakness, flaccid paralysis, } \\
\text { seizures, respiratory failure, } \\
\text { tachycardia }\end{array}$ \\
\hline \multirow[t]{2}{*}{ Blistering agents } & \multirow[t]{2}{*}{$\begin{array}{l}\text { Nitrogen mustard and sulfur } \\
\text { mustard (mustard gas) }\end{array}$} & \multirow[t]{2}{*}{ Inhalation } & $\begin{array}{c}\text { Acute: skin, eye and lung } \\
\text { damage (pulmonary edema } \\
\text { and pulmonary hemorrhage), } \\
\text { skin blistering }\end{array}$ \\
\hline & & & $\begin{array}{c}\text { Chronic: lung damage, } \\
\text { neutropenia, pancytopenia }\end{array}$ \\
\hline Asphyxiants & $\begin{array}{c}\text { Carbon monoxide, chlorine, } \\
\text { phosgene, hydrogen sulfide } \\
\text { gases }\end{array}$ & Inhalation & $\begin{array}{l}\text { Upper airway distress, skin } \\
\text { and eye irritation, fatal } \\
\text { pulmonary edema and acute } \\
\text { respiratory distress syndrome }\end{array}$ \\
\hline Blood agents & Cyanide & $\begin{array}{l}\text { Skin absorption, inhalation } \\
\text { and ingestion }\end{array}$ & $\begin{array}{c}\text { Severe distress, tachycardia, } \\
\text { cyanosis, hypotension, severe } \\
\text { metabolic acidosis }\end{array}$ \\
\hline- & Hydrofluoric acid & $\begin{array}{l}\text { Skin absorption, inhalation } \\
\text { and ingestion }\end{array}$ & $\begin{array}{l}\text { Severe pain in exposed area, } \\
\text { gastrointestinal distress, } \\
\text { vomiting, cardiac arrhythmias }\end{array}$ \\
\hline
\end{tabular}

need for the development of sensitive and specific diagnostic tools for CWA. In fact, simple synthesis and high toxicity [15] are the major reasons that have led to the significant use of these chemical materials during various wars, for example in Syria 2017, and for individual assassinations - February 2017 in Kuala Lumpur [16-19]. The rapid detection of these toxic agents in the environment, public places or workplaces and the monitoring of an individual's exposure to CWA become increasingly vital for homeland security and environment monitoring.

Table 1 shows the type of CWA and their clinical symptoms on the human body [20].

The available sensing materials have limitations in the detection of the gases mentioned in Table 1; also there are difficulties to use sarin in experimental tests due to the highly dangerous and fatal effects on the human body [21, 22]. One of the leading candidates in the field of detectors for chemical warfare agents is the chemiresistive sensor. There are several advantages such as small size, lightweight simple structure, high sensitivity and signal-tonoise ratio that have made it possible to realize low power, low cost, and portable sensing devices for warfare agents. Monitoring chemicals, gaseous, and vapor concentrations is a vital activity in the liquid industry, power plants, vehicle emissions, environmental safety, earth science, and many other extended circumstances. Chemical sensors for different specific structures with varying degrees of sensitivity and discrimination are commercially available [23]. The key attributes expected for the development of a sensor include sensitivity in the parts per million (ppm) to billion $(\mathrm{ppb})$ range where trace levels are involved, absolute discrimination, mild operation temperature, low power consumption, practical size, volume and mass, and low cost for large-scale applications [24].

\section{DIMETHYL METHYLPHOSPHONATE (DMMP)}

Considering the high toxicity of sarin and its fatal affect on the human body, DMMP is known as a sarin gas simulant because it has a similar structure. The chemical formulas of sarin and DMMP are $\mathrm{C}_{4} \mathrm{H}_{10} \mathrm{FO}_{2} \mathrm{P}$ and $\mathrm{C}_{3} \mathrm{H}_{9} \mathrm{O}_{3} \mathrm{P}$, respectively, and both belong to the family of organophosphate compounds [25]. The chemical structure of $-\mathrm{P}=\mathrm{O}$ - in the DMMP compound are an important group for the detection and further research on the lab scale of this simulant is significantly helpful in providing a reference and basis for establishing an effective method of detecting real nerve agents from sarin. Other than DMMP, diisopropyl methylphosphonate (DIMP), diisopropyl fluorophosphates (DFP), triethylphosphate (TEP) and diethyl ethylphosphate (DEEP) have been used as sarin simulants. While the chemical functionality of sarin is better reproduced by DIMP and DFP, DMMP has been the most common chemical warfare agent simulant (CWAS) for such research due to its low toxicity and ease of handling [26, 27]. Although CWAS are much less toxic than CWA, personal protective equipment and carefully designed experimental facilities are required to handle these compounds. For example, DIMP and DFP are acetylcholinesterase inhibitors, while DMMP is listed in Schedule-2 of the Annex of Chemical Weapons Convention as a precursor for the production of sarin [28]. DMMP will react with thionyl chloride $\left(\mathrm{SOCl}_{2}\right)$ to produce methylphosphonic acid dichloride $\left[\mathrm{MeP}(\mathrm{O}) \mathrm{Cl}_{2}\right]$, which is used in the production of sarin nerve agents.

The structures of the nerve agent sarin and its simulant DMMP are shown in Formulas (I) and (II) [29]. Table 2 gives the chemical properties of DMMP and sarin gas $[30,31]$. 


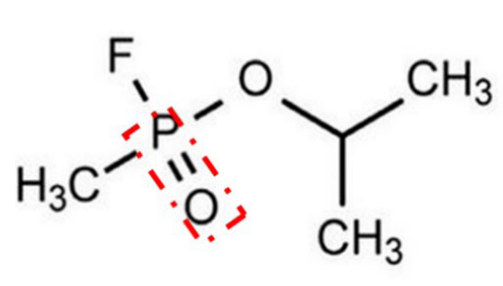

Sarin

(I)

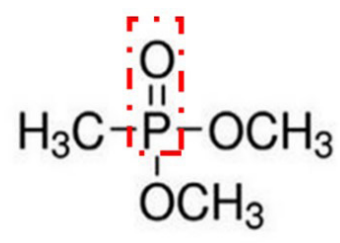

DMMP

(II)
$\mathrm{T}$ a b 1 e 2. Chemical properties of DMMP and sarin gas

\begin{tabular}{l|c|c}
\hline \multicolumn{1}{c|}{ Properties } & Sarin & DMMP \\
\hline Molecular mass, g/mol & 140.1 & 124.08 \\
Boiling point, ${ }^{\circ} \mathrm{C}$ & 158 & 181 \\
Vapor pressure at $20^{\circ} \mathrm{C}, \mathrm{mmHg}$ & 2.1 & $<0.1$ \\
Liquid density at $25^{\circ} \mathrm{C}, \mathrm{g} / \mathrm{cm}^{3}$ & 1.10 & 1.145 \\
Acute oral toxicity $\mathrm{LD} 50, \mathrm{mg} / \mathrm{kg}$ & 0.55 & 8210 \\
\hline
\end{tabular}

Based on the study of Trotochaud et al. (2019), in DMMP, a methoxy group (-O-CH$)$ is attached to phosphorus $\left(\mathrm{P}-\mathrm{O}-\mathrm{CH}_{3}\right)$ instead of the fluorine $(\mathrm{F})$ in the sarin molecule (P-F). During decomposition, DMMP binds to a metal oxide surface just like sarin, via its phosphoryl oxygen. Nucleophilic attack by oxygen atoms on the surface hydroxyl groups at the phosphorus center results in a bidentate structure as illustrated in Scheme B (b). Instead of the analogous P-F bond in sarin, for DMMP, its methoxy group is first cleaved and protonated to generate methanol [32, 33]. This leads to the formation of (adsorbed) methyl methylphosphonate (MMP). In the following reaction [Scheme B (c)], the second methoxy group is cleaved, analogously to the cleavage of the isopropyl group for sarin. The phosphorus-containing product is methylphosphonate (MP). These reaction similarities make the work on the decomposition of DMMP relevant as providing insight into the reactivity of carbon nanotubes and their functionalization with polymers towards sarin.

Scheme $C$ shows the schematic diagram of the initial steps of the decomposition of DMMP on the surface of metal oxide that produces MMP.

Recently, using different strategies, the detection method of sarin gas has been the subject of numerous

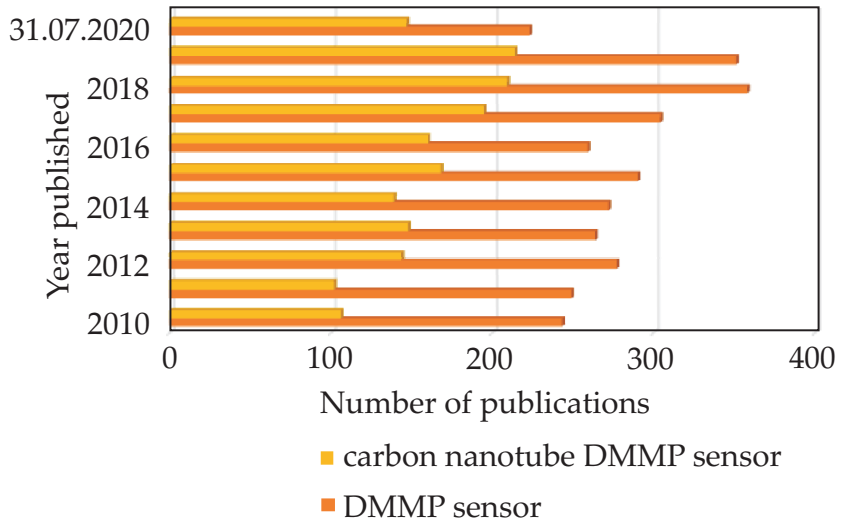

Fig. 1. A histogram of published manuscripts focused on "carbon nanotube DMMP sensor" and "DMMP sensor" as keywords

investigations [34-36]. It is obvious that sensing devices are required to detect extremely low sarin concentrations and, more importantly, to be able to respond very rapidly. At the same time, the costs associated with sensor production and maintenance are important factors that need to be taken into consideration when proposing new sensors. The thorough, atom-scale understanding of the sensing mechanism, the gas adsorption mechanism and its impact on the sensing material is expected to be extremely helpful to tune the respective devices and eventually to realize competitive sensor components for industrial production. For experimental work, the availability of a benign model system replacing sarin is of crucial importance [37].

A search was performed using the Google Scholar database (adapted on 31 st July 2020) using the keywords "carbon nanotubes dmmp sensor" and "dmmp sensor", and it was found that the number of manuscripts focusing on both keywords has increased for years even though it shows an inconsistent trend as shown in Fig. 1.

This is alarming as the safety for people and country are one of the important characteristic factors that need to be considered for development, national security and stability. This review serves to introduce the relation between DMMP and sarin gas, the characteristics of DMMP and highlight research on the development of sensing materials from carbon nanotube (CNT)-based conducting polymers for DMMP gas detection.
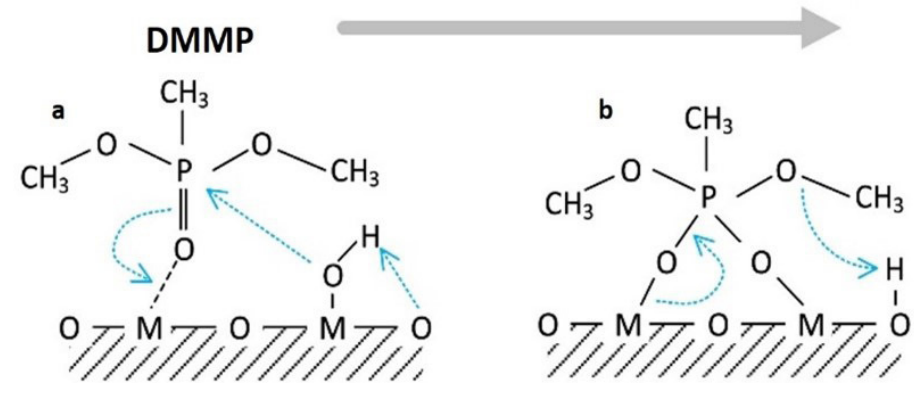

$\mathrm{MMP}+$ methanol

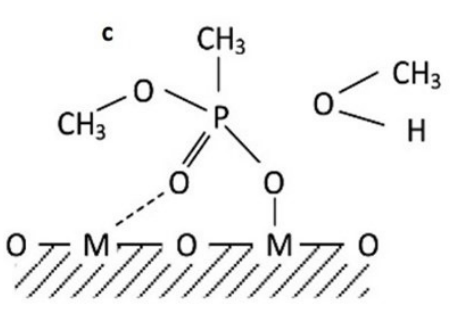

Scheme C. Schematic diagram of the decomposition reaction of DMMP on a metal oxide surface 


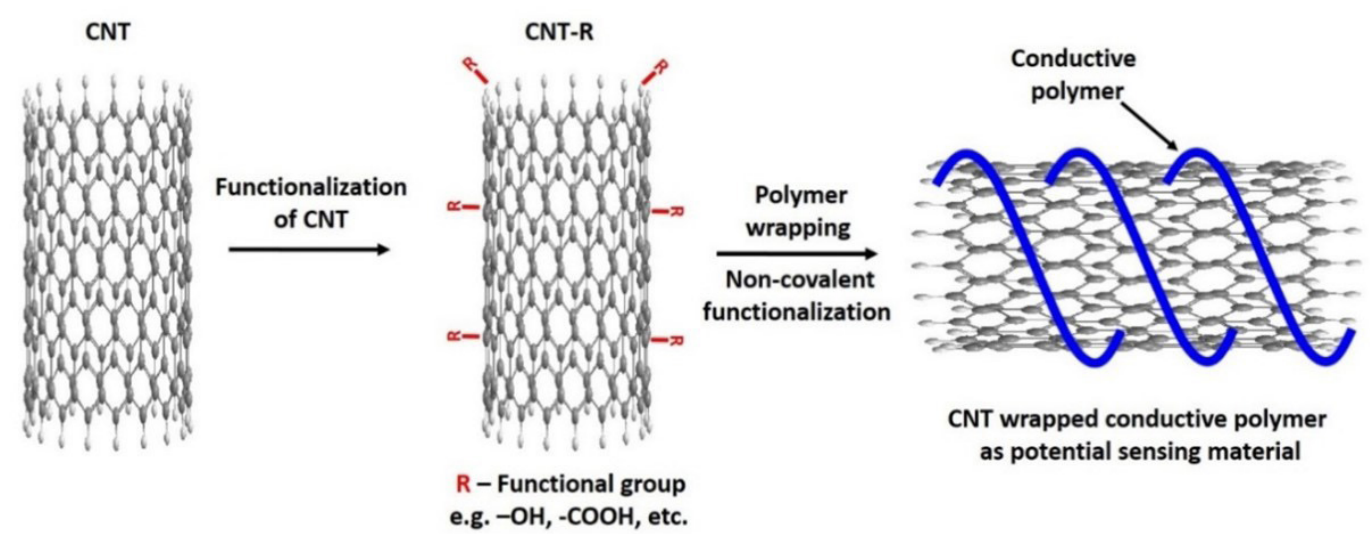

Scheme D. Schematic diagram of CNT wrapped conducting polymer for chemical sensor

\section{DEVELOPMENT OF CNT WRAPPED CONDUCTIVE POLYMER-BASED SENSORS}

To address the needs of CWA detectors, carbon nanotube (CNT)-based sensors have recently been investigated. CNTs have intriguing properties, including chemical stability demonstrated as effective ultrasensitive chemical and biological sensors because of their high ratio of surface-to-volume and their unique electrical properties [38-40]. The reported CNT-based sensors are generally highly sensitive, respond quickly, and operate at room temperature [41-44]. Although pure CNT-based sensors are easy to fabricate and can operate at room temperature, their low response and relatively long and slow response times are unresolved issues. To overcome these shortcomings and improve selectivity, several surface modifications by covalent and non-covalent functionalization with polymers [45-47], or with catalytic metal nanoparticles [48-50], have been explored. Metal oxides are the most widely used materials for sensing materials. Despite their sensitivity, the applications of these materials have been limited by high power consumption and poor selectivity.

Scheme D shows the schematic diagram of a conductive polymer wrapped CNT for the detection of chemical gasses.

Referring to Ying et al. (2007), analyzing nerve agents in environmental and biological samples is usually carried out using analytical techniques that have a very high sensitivity, reliability and precision [51], such as gas chromatography (GC) [52, 53], liquid chromatography (LC) $[52,54]$, gas chromatography mass spectrometry (GCMS) $[52,55,56]$, ion chromatography (IC) [57], atomic emission detection (AED) [58], capillary electrophoresis (CE) [54, 59], CE coupled with flame photometry [54], CE with conductivity detection [60]. In spite of these advantages, the techniques require expensive instrumentation and highly trained personnel, as well as being time consuming and incompatible with field analysis. To meet the prerequisites of rapid warning and field deployment, compact low-cost instruments are highly desirable for facilitating the function of on-site monitoring of nerve agents.
Organic polymers are one of the primary materials utilized in gas sensing systems. Some conducting polymers perform like semiconductors due to their heterocyclic structure. Thus, reversible changes in the sensing layer's conductivity can be detected upon polar analyte adsorption on the surfaces at room temperature [61]. This effect is believed to be caused by the charge transfer between gas molecules and the polymer or the polymer film's swelling [62]. This sensing response has intensively driven the motivation on the research and development of high sensitivity and selective gas or chemical sensors by tailoring the structure of different organic polymers and the fabrication of nanocomposites.

Non-conductive polymers can also be used as gas sensors. For some polymers, the bulk dissolution of gas into the film can cause changes in their physical properties [62]. Since most physical property changes are not readily detectable, researchers have tried to integrate polymers with other functional sensing elements such as with CNTs and some metal oxides in order to achieve easier and improved detection limits. For example, research on the chemical sensing characteristics of functionalized CNTs with polymer-coated resonators was reported by [46, 63-65] for the adsorption of interested analytes: there are volumetric changes in the polymer matrix. This leads to a distinct change in percolation-type conductivity around a critical composition of the nanomaterial, which is known as the "percolation threshold". Generally, the percolation threshold is dependent on the shape and amount of the conducting particles. A nanocomposite containing conductive nanoparticles with higher aspect ratio shows lower percolation thresholds and higher sensitivity [66].

Chemiresistor devices for chemical warfare agent detection based on polymer wrapped single walled carbon nanotubes (SWCNTs) were fabricated using a derivatized poly(3,4-ethylenedioxythiophene) (PEDOT) with a hexafluoroisopropyl group (HFIP)/SWCNTs composite [67]. The results show that the pendant HFIP group on the polymer enhances the sensitivity to a nerve agent mimic, dimethyl methylphosphonate, in both nitrogen and air environments to concentrations as low as $5 \mathrm{ppm}$ and 
a)

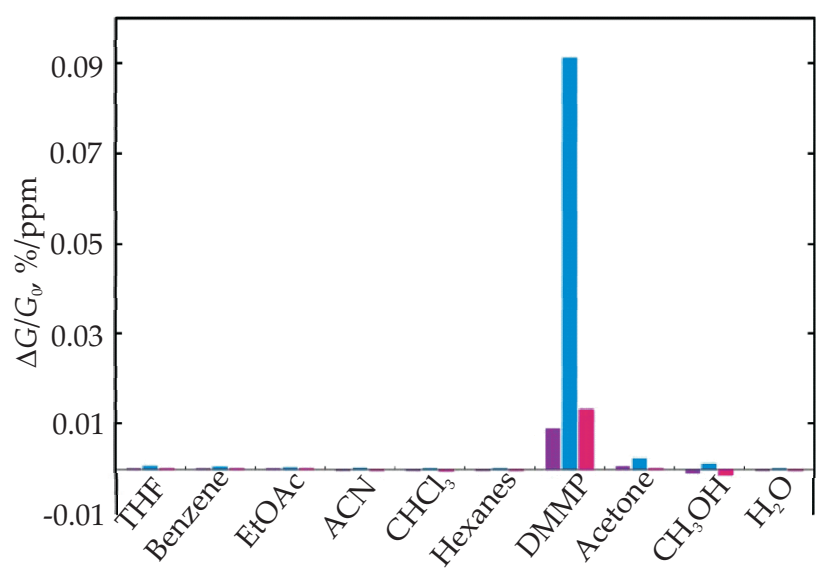

b)

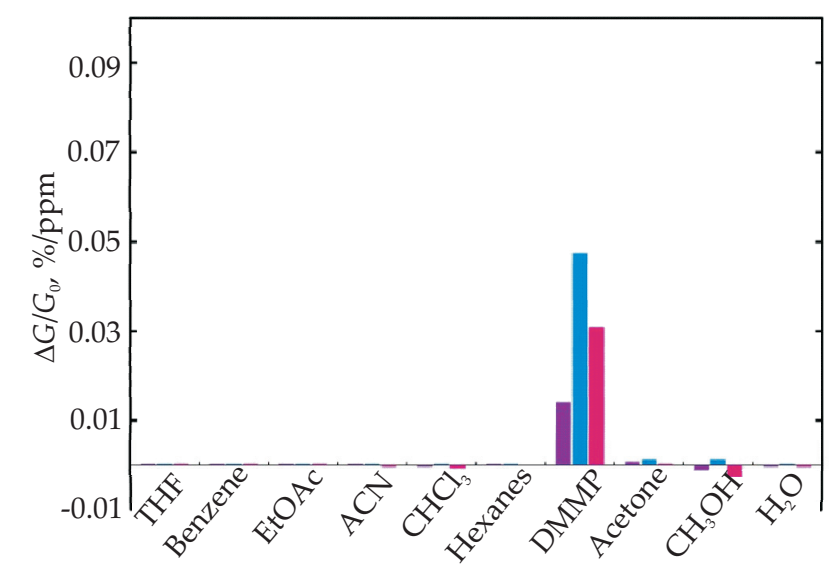

Fig. 2. Change in conductance response ratio for PEDOT-HFIT/SWCNT to DMMP and VOCs in: a) $\mathrm{N}_{2}$, b) air (24\% RH)

11 ppm, respectively. Additionally, these PEDOT-HFIP/ SWCNTs derivative sensor systems experience negligible changes in device performance over the course of two weeks under ambient conditions. The results also show strong responses to 5 ppm DMMP and a calculated detection limit of $2.7 \mathrm{ppm}$ in $\mathrm{N}_{2}$. The same devices in a "real world" environment, where air has $24 \%$ relative humidity $(\mathrm{RH})$, experienced a strong response at $11 \mathrm{ppm}$ and a detection limit of $6.5 \mathrm{ppm}$. Figure 2 shows the chemiresistive response ratio $\left(-\Delta G / G_{0^{\prime}} \% / \mathrm{ppm}\right)$ for PEDOT-HFIP/ SWCNTs to volatile organic compounds (VOCs) in $\mathrm{N}_{2}$ (a); chemiresistive response ratio for PEDOT-HFIP/SWCNTs to VOCs in air (24\% RH) (b).

An interesting result in Fig. 3 shows an increase in conductance for the PEDOT in THF/SWCNTs (THF - tetrahydrofuran) and PEDOT in DMF (dimethylformamide) composites upon exposure to acetonitrile, chloroform, hexanes, methanol and water. This may be explained by a secondary doping effect [68]. Considering that the SWCNTs are naturally p-doped by molecular oxygen [69] and that the polymers are strong electron donors, the carrier levels in the SWCNTs will be reduced by strong charge transfer interactions or electron donation from the polymers to nanotubes. Some of the solvents may reduce these interactions and thereby affect an increase in carrier density. If the organic vapor molecules do not have strong interactions with the SWCNTs that pin or scatter the carriers, increased carrier levels will contribute to an increased rise in conduction.

Chemical sensors based on the nanocrystalline structure of a $\mathrm{Co}_{3} \mathrm{O}_{4} / \mathrm{Au}$ decorated multi-walled carbon nanotubes/polypyrrole (MWCNTs/PPy) hybrid composite was successfully synthesized via a hydrothermal process and the sensitivity properties of DMMP were characterized [70]. The hybrid composite deposited on quartz via sensors demonstrated an excellent response to DMMP vapor at room temperature and low power consumption at a sampling voltage of $300 \mathrm{mV}$. The enhancement was achieved by the combination of $\mathrm{Co}_{3} \mathrm{O}_{4} / \mathrm{Au}$ nanoparticle composite that actively reacts with the gases, and the formation of an electrical continuum between $\mathrm{Co}_{3} \mathrm{O}_{4}$ and MWCNTs/PPy. Thus, the hybrid composite showed a rapid, reversible, and reproducible response to DMMP

b)

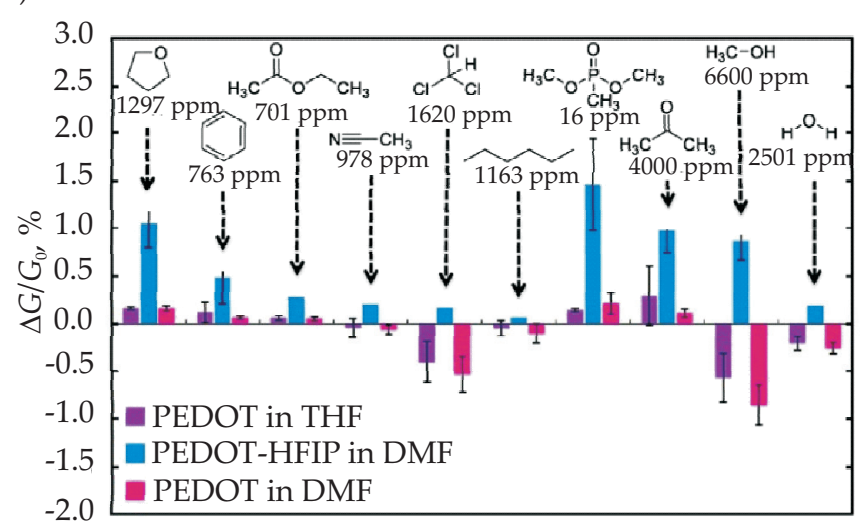

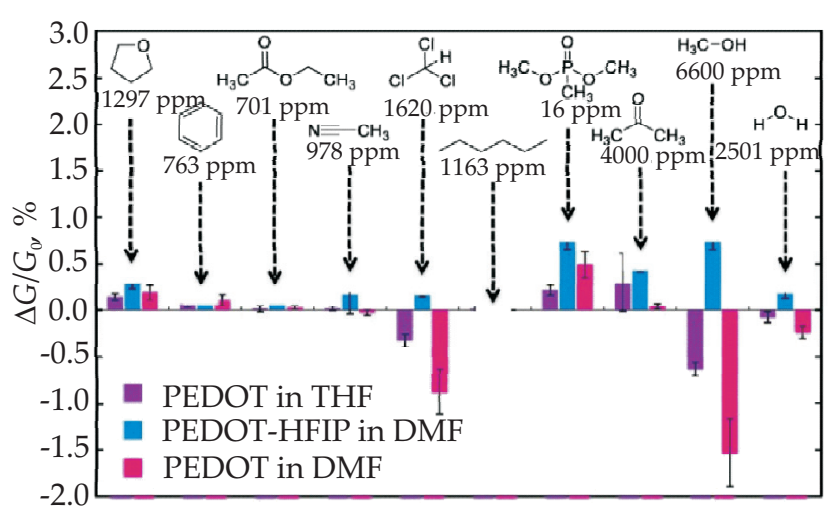

Fig. 3. Chemiresistive responses averaged across P1 to P3/SWCNT devices to $60 \mathrm{~s}$ exposures of VOCs at a flow rate of $200 \mathrm{~cm}^{3} / \mathrm{min}^{2}$ in: a) dry $\mathrm{N}_{2}$, b) air ( $\left.24 \% \mathrm{RH}\right)$ 
a)

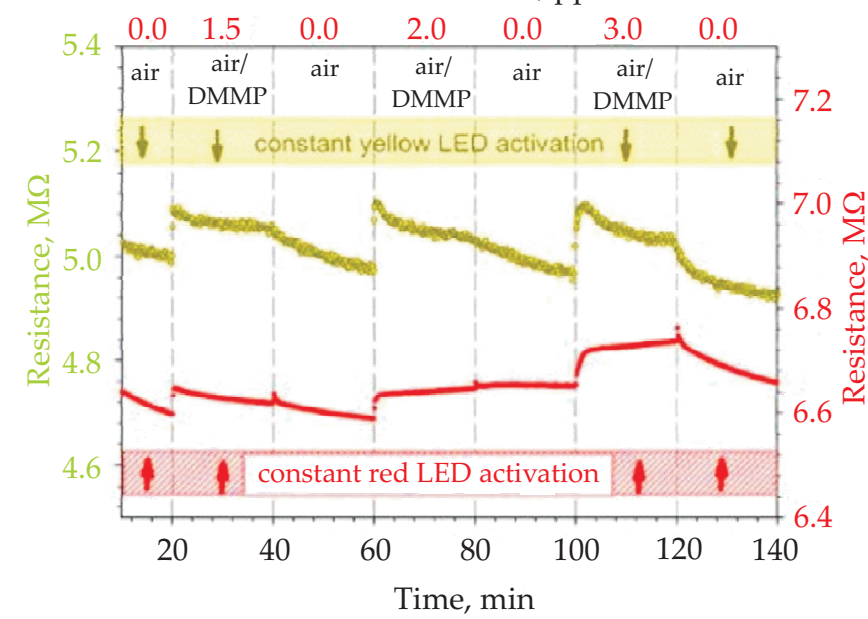

b)

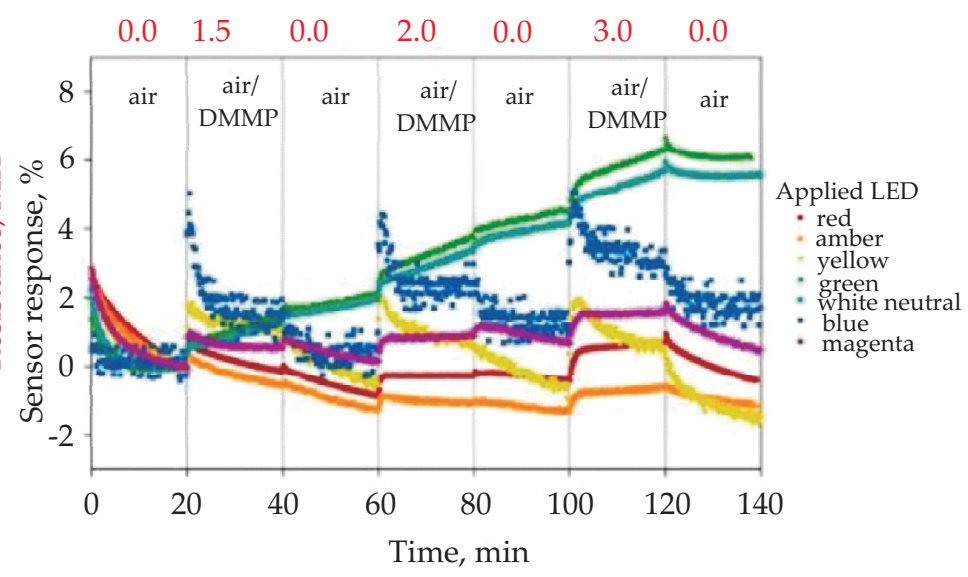

Fig. 4. Time-dependent: a) resistance at room temperature of the RR-P3HT layer activated by red and yellow diodes in the presence of three different DMMP concentrations $(1.5,2$ and 3 ppm), b) sensor responses at room temperature of the RR-P3HT layer activated by seven different diodes

vapor, indicating its promise as a gas sensor for highperformance detection.

Another interesting study on light-activated regioregular poly(3-hexyltiophene) (RR-P3HT) photoconductive polymer sensing properties of nerve agent simulant, DMMP, was presented in [71]. The studied material was activated and enhanced by light-emitting diodes (LED) that emitted light of different wavelengths (Fig. 4). The sensing properties of RR-P3HT are considerably enhanced upon exposure to blue $(475 \mathrm{~nm})$ and yellow $(575 \mathrm{~nm})$ light excitation at room temperature. However, excitation by low wavelength light (blue) caused degeneration of the sensing material, resulting in lower stability. In the case of the yellow light, the degeneration was much slower and the limit of detection was $0.4 \mathrm{ppm}$. The studied material exhibited high selectivity, as it did not respond to $6 \mathrm{ppm}$ of acetone and methanol vapors.

Powroznik et al. [71] explained the sensing mechanism between the P3HT with DMMP vapors based on a conductivity study. Polythiophenes (PTh), including P3HT, have a Lewis base nature due to the free electron pairs on their sulfur atoms [72] and are hypothesized to form adducts with Lewis acids. This is the case particularly with boron trifluoride, which is commonly used both to facilitate polymerization of thiophene-based monomers and to improve the conductivity of thiophene-bearing conjugated polymers [73]. The aforementioned improvement in conductivity stems from doping-induced charge carriers being produced due to the altered electron density distribution across the P3HT chain; which in turn are caused by interactions with Lewis acids as any interactions between P3HT and another Lewis base should adversely affect the properties of $\mathrm{P} 3 \mathrm{HT}$, particularly its conductivity. The DMMP molecule has a Lewis base nature [74], therefore the loss of $\mathrm{P} 3 \mathrm{HT}$ conductivity upon exposure can be considered in line with the above hypothesis. Another possible mechanism that explains the declining P3HT conductivity upon exposure to DMMP may be based on an increase in inter-chain distance, caused by the incorporation of DMMP molecules into the RR-P3HT matrix, which affects the electron hopping between RR-P3HT chains. This is matched with the results obtained by Wang et al. [75], who postulate that DMMP induces conformational changes in PTh chains, which likely also significantly contribute to the formation and decay of conductive paths in the film, directly affecting the changes in its macroscopic conductivity.

Chemiresistors based on an HFIP-PT/SWCNTs (HFIP-PT - hexafluoroisopropanol substituted polythiophene) hybrid system were shown to be highly sensitive and selective for DMMP gas detection [75]. A stable dispersion of SWCNTs were prepared by sonication after mixing with $50 \mathrm{wt} \%$ HFIP-PT or P3HT. The sensor response is fast and reproducible even at low analyte concentrations. The sensor showed that there is $8 \%$ conductance change upon exposure to $0.6 \mathrm{ppm}$ of DMMP. Next, the sensor displayed a linear logarithmic response to analyte concentrations over 2 decades of concentration. The deposited SWCNTs from HFIP-PT, P3HT stabilized dispersions, and non-stabilized dispersions were compared by their selectivity and sensitivity. Moreover, the

H-bonding ability of HFIP-PT/SWCNTs greatly increased the response and selectivity for DMMP compared to P3HT/SWCNTs and bare SWCNTs. Hence, the conductive polymer associated with CNTs provided an increased sensitivity due to strong

H-bonding interactions with the analyte (Scheme E) [76].

A chemiresistive sensor by the chemical polymerization and coating of polyaniline (PANI), poly[2-methoxy5-(2-ethyloxy)-p-phenylenevinylene], or commercial poly(methyl methacrylate) (PMMT) on MWCNTs [77] showed that the MWCNTs-PANI sensor provided high sensitivity, excellent selectivity, good reproducibility, and long stability for all the investigated different concentra- 

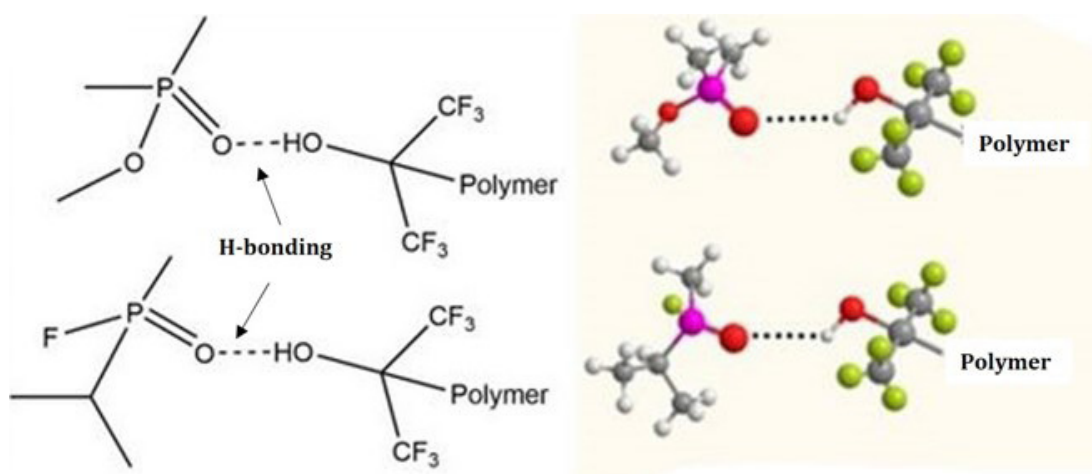

\section{DMMP-HBA Polymer}

Sarin-HBA Polymer

Scheme E. H-bonding interactions between DMMP, sarin and hydrogen bond acidic (HBA) polymer

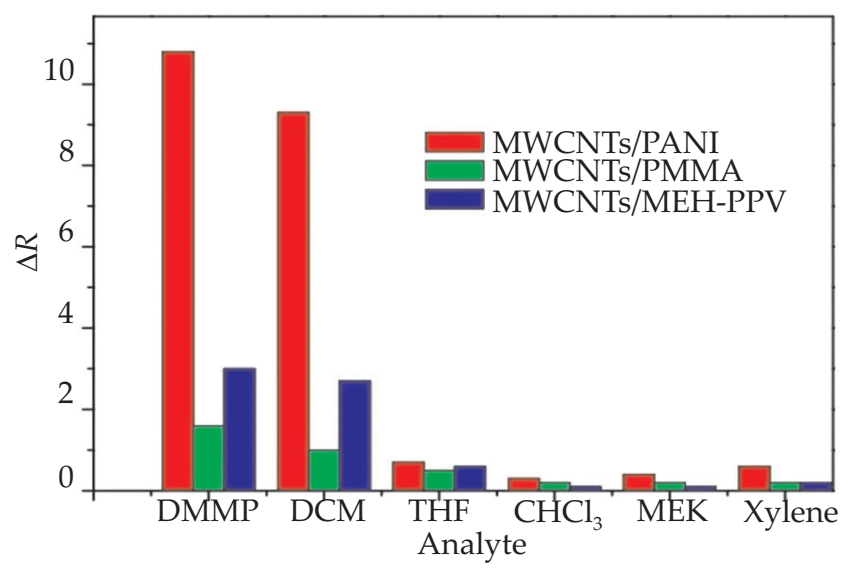

Fig. 5. Relative resistance responsivity of MWCNTs-polymer sensing films against six different analytes at $50^{\circ} \mathrm{C}$

tions of analyte at a temperature of $50^{\circ} \mathrm{C}$. The comparison of three MWNT-polymer composite sensing films in three systems exhibited the highest response intensity or responsivity to DMMP vapor, implying that MWCNTsPANI's excellent responsiveness is due to the nature of the PANI matrix itself. The relative sensitivity responsiveness is depicted in Eq. (1)

$$
\Delta R=\log \left(R_{\text {gas }}-R_{\text {air }}\right)
$$

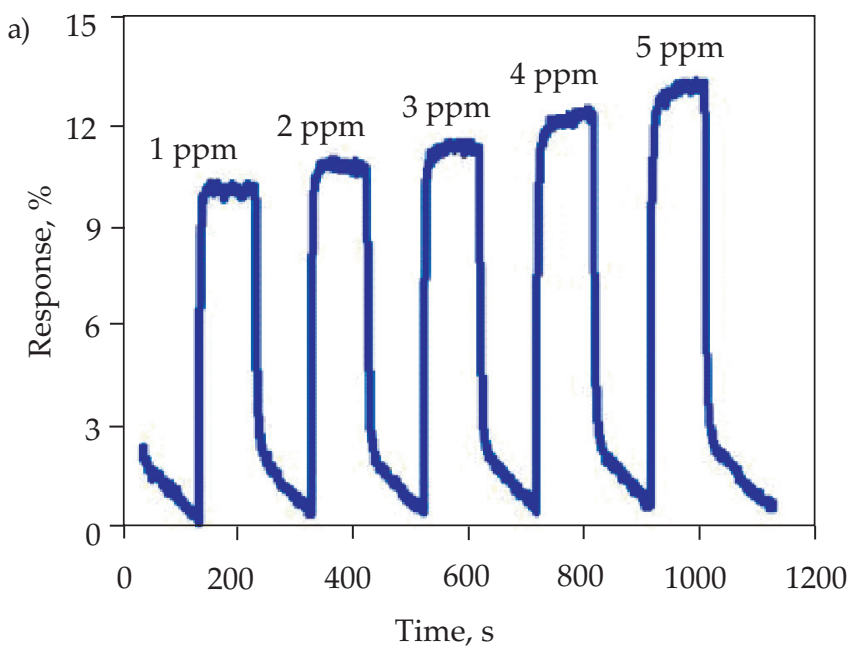

where: $R_{\text {air }}$ - the original resistance, $R_{\text {gas }}$ - the maximum resistance of the film upon exposure to the simulated chemical warfare and organic solvent vapors. The relative responsivities $(\triangle R)$ of the MWCNTs-PANI system for DMMP, DCM, THF, $\mathrm{CHCl}_{3}, \mathrm{MEK}$ and xylene at $50^{\circ} \mathrm{C}$ exposures are approximately to $10.8,8.6,0.7,0.3,0.4$, and 0.6, respectively (Fig. 5).

It was found that changes in film resistance were caused by changes in interlayer distances, which are induced by polymer swelling upon gas absorption. Also, the attribution of hydrogen bond interactions between the solvent molecules and the PANI chains greatly affected the sensitivity towards the gas sensor.

According to Yoo et al. [78], a composite sensor composed of SWCNTs and PANI was synthesized to obtain effective composites with good uniformity. The composites were drop-cast onto an oxidized substratum of Si patterned with Pd electrodes. At room temperature, even at minuscule concentrations, SWCNTs-PANI composite sensors exhibited clear, sharp response curves for DMMP in air. The response and response times were $27.1 \%$ and $5.5 \mathrm{~s}$, respectively, at $10 \mathrm{ppm}$ DMMP, representing a major improvement over the pure SWCNTs network sensors previously reported. Fig. 6a shows the real-time sensor sensitivities at various DMMP concentrations. The response clearly increases linearly with increased DMMP concentration, as summarized in Fig. 6b. The response

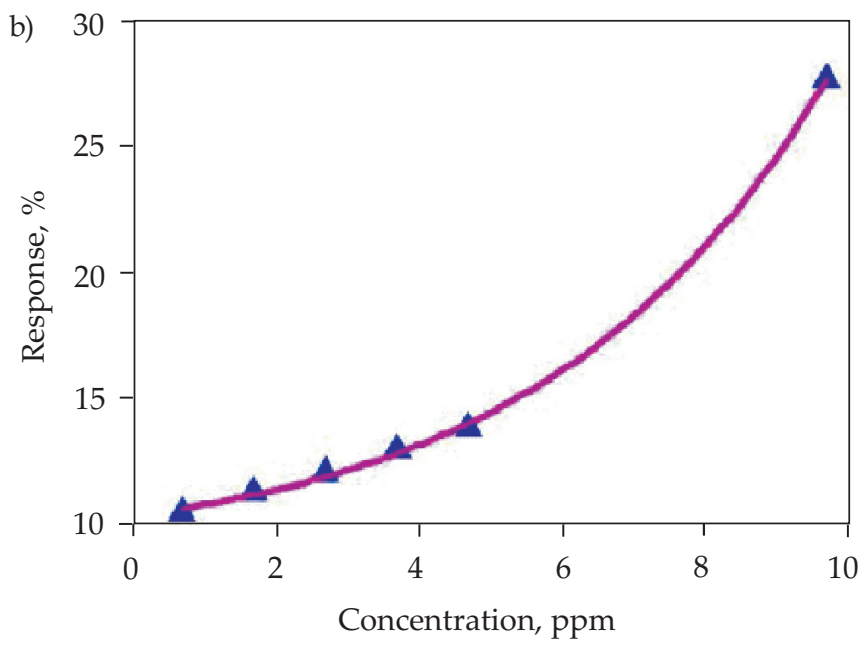

Fig. 6. a) Real-time response curves as a function of DMMP concentration at room temperature, b) response versus DMMP concentration 

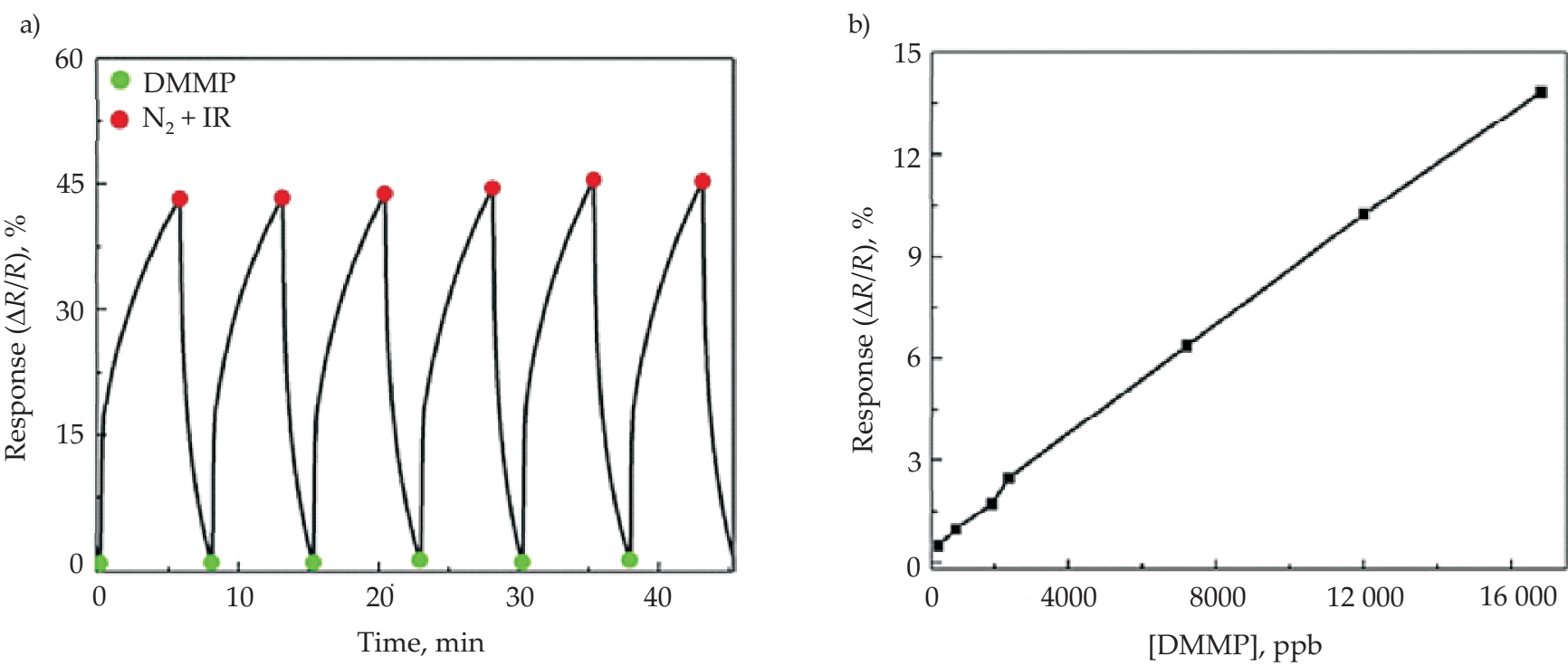

Fig. 7. a) The repeatable response of sensor for $1200 \mathrm{ppm}$ DMMP to check the reproducibility of the sensor, b) change in the response of the sensor for DMMP ranging from $480 \mathrm{ppb}$ to $16000 \mathrm{ppb}$

is well-scaled for a low DMMP concentration range, although the scaling trend is not monotonic. The linear correlation between the SWCNTs-PANI sensor response and DMMP concentration arises from the frequency of DMMP adsorption is generally proportional to its concentration.

A flexible single-walled carbon nanotube (SWCNTs) resistive sensor was functionalized with 4-(hexafluoro2-hydroxy isopropyl) aniline (HFiP-1) to enhance the response of the sensor towards DMMP vapors at room temperature. The response of the functionalized sensor was $16.0 \%$ for 24 ppm DMMP and increased 3.7 fold compared to the pristine sensor. In addition, the functionalized sensor showed a fast response time, recovery time and good repeatability at low and higher exposed concentrations of DMMP in comparison to the pristine sensor. The response of the sensor exposed to different

a)

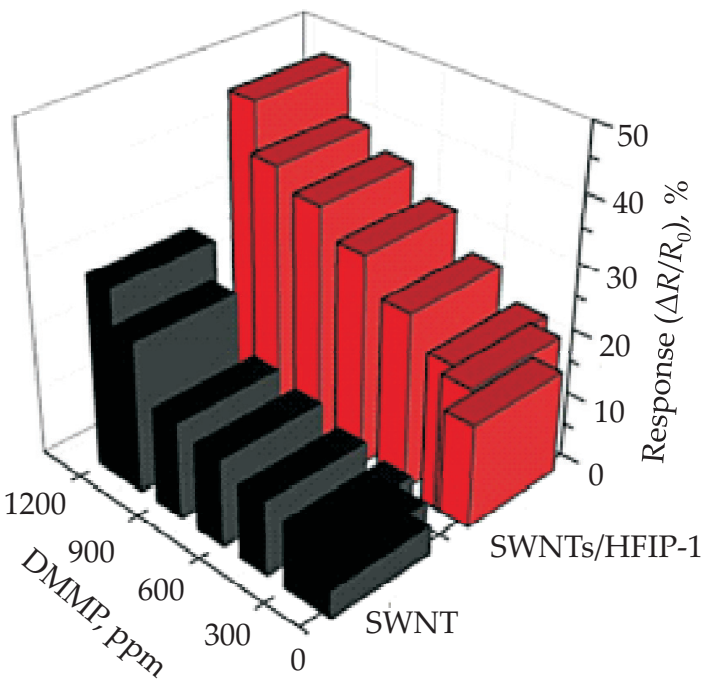

concentrations of DMMP at room temperature is shown in Fig. 7.

The chemical sensor gave a response of $16.0 \%$ to 24 ppm and $47.0 \%$ to 1200 ppm of DMMP. The chemical sensor showed a fast response and recovery. It recovered to baseline levels even at higher exposed concentrations when illuminated with IR in the presence of $\mathrm{N}_{2}$. In the graph, green marks indicate DMMP is switched on and red marks indicate $\mathrm{N}_{2}$ and IR light are switched on. The sensor was able to resolve the different exposed concentrations and showed good reproducibility. The response of pristine and functionalized sensors to different concentrations of DMMP ranging from 24 ppm to 1200 ppm is shown in Fig. 8 [79].

Research on a gas sensor based on a hybrid polymer dispersed liquid crystal (PDLC) material doped with MWCNT as sensing film was used in [80]. The orienta-

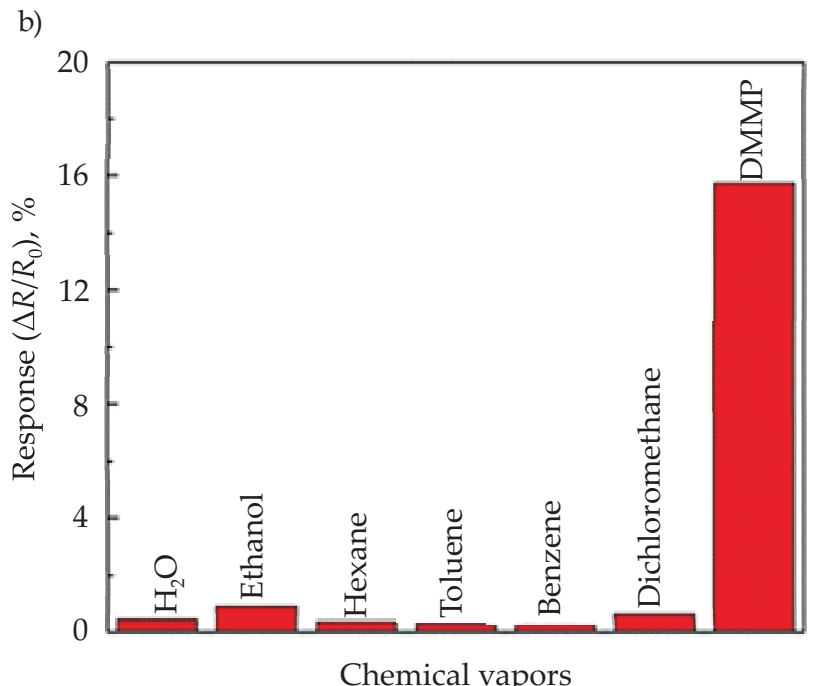

Fig. 8. a) Plot of DMMP response towards pristine and functionalized SWCNTs sensor, b) comparable results of selective response of sensor for DMMP 
tion ordering transitions of MWCNTs and liquid crystal (LC) caused by DMMP vapor molecules altered the conductivity of MWCNT networks, thus shifting the electrical resistance of the sensing film. A linear sensor response was achieved for DMMP concentrations from 5 ppm (1.2\% resistance change) to 250 ppm (62.5\% resistance change). The response time was approximately 125 $\mathrm{s}$, and the measured results indicated favorable reproducibility.

Based on Chang et al. (2009), a study of DMMP-sensing based on composites of MWCNTs and PANI, their sensor was reported to show a response of $1 \%$ at $332 \mathrm{ppm}$ of DMMP concentration. However, the study showed that the PANI resulted in a reduction in response time whereas any single material of SWCNTs, MWCNTs, and PANI had a limited response. Besides that, the sensitivities of the MWNTs-polymer films for the six solvents (DMMP, DCM, chloroform, THF, MEK, xylene) in decreasing order were MWNTs-PANI > MWNTs-MEH-PPV > MWNTs-PMMA, which corresponds to an order of decreasing conductivity [77].

Yuan and Chang reported on the MWNT-PANI sensor for the detection of $\mathrm{CH}_{3} \mathrm{OH}, \mathrm{CHCl}_{3^{\prime}} \mathrm{CH}_{2} \mathrm{Cl}_{2}$ and DMMP as a nerve agent simulant [81]. A chemiresistive multilayer sensor was fabricated by drop-coating PANI solution onto chemically modified MWNT. The experimental results showed that $1 \mathrm{wt} \%$ MWNTs and 10, 5, $1 \mathrm{wt} \%$ PANI sensor samples exhibited high sensitivity, excellent selectivity and good reproducibility to DMMP and DCM vapors. It was observed that upon exposure to different chemical vapors, the sensing film swelled reversibly and caused changes in resistance after exposure to $\mathrm{CH}_{3} \mathrm{OH}$ (2122 ppm), $\mathrm{CHCl}_{3}$ (2238 ppm), $\mathrm{CH}_{2} \mathrm{Cl}_{2}$ (481 ppm) and DMMP (332 ppm). While when the sensing film is transferred back to dry air, the electrical resistance returned to the original value rapidly, demonstrating a good restoration performance.

\section{CONCLUSIONS}

Advances in chemical sensors applied to detect DMMP, a CWA sarin simulant, have been increasingly reported in recent years. High sensitivity and selectivity, combined with the ability of low power, low cost, ease of use and demanded mild operation conditions are essential in the development of chemical sensors to counter the potential for the safety of the nation and also for other benefits. Although CNTs have demonstrated their great potential for gas sensing materials experimentally, there are still several challenges remaining before their real practical application can be realized. Synthesis of pure and ideal CNTs is still challenging and costly. Other than that, factors such as selectivity of the chemical sensor is the major issue being studied worldwide over a broad range and a multiple sensing ability. The present understanding about the current research should provide fundamental knowledge for a new technology in chemical sensors.
Future advances in sensing performance (e.g., sensitivity, selectivity, and stability) and system integration, combined with technology supported by chemistry and materials engineering are envisioned for the accurate, realtime and consistent monitoring in safety applications.

\section{ACKNOWLEDGMENTS}

Financial support from Newton fund's Program and Malaysia Partnership and Alliances in Research (MyPAiR) for ISIS-NEWTON/2019/SG/01 and Chemical Defence Research Centre (CHEMDEF) for a research grant (UPNM/2018/ CHEMDEFF/ST/3) are gratefully acknowledged.

\section{REFERENCES}

[1] Dar M.A., Kaushik G., Chiu J.F.V.: "Abatement of Environmental Pollutants, Trends and Strategies", 2020, pp. 25-66. https://doi.org/10.1016/B978-0-12-818095-2.00002-3

[2] Weihui W., Shaohui S., Jian L. et al.: Analyst 2020, 145 (16), 5425. https://doi.org/10.1039/D0AN00878H

[3] Sulaiman I.S.C., Chieng B.W., Pojol F.E. et al.: Forensic Toxicology 2020, 38 (2), 297. https://doi.org/10.1007/s11419-019-00513-x

[4] John H., Balszuweit F., Steinritz D. et al.: "Handbook of toxicology of chemical warfare agents", 2020, pp. 875-919. https://doi.org/10.1016/B978-0-12-819090-6.00052-0

[5] Mukhopadhyay S., Schoenitz M., Dreizin E.L.: Defence Technology 2020.

https://doi.org/10.1016/j.dt.2020.08.010

[6] Costanzi S., Machado J.H., Mitchell M.: ACS Chemical Neuroscience 2018, 9 (5), 873.

https://doi.org/10.1021/acschemneuro.8b00148

[7] Jun J., Lee J.S., Shin D.H. et al.: Journal of Materials Chemistry A 2017, 5 (33), 17335. https://doi.org/10.1039/C7TA02725G

[8] Thiermann H., Aurbek N., Worek F.: Treatment of Nerve Agent Poisoning 2016, 2, 1. https://doi.org/10.1039/9781782628071-00001

[9] Kushwaha M., Verma S., Chatterjee S.: Journal of Environmental Quality 2016, 45 (5), 1478. https://doi.org/10.2134/jeq2016.03.0100

[10] Gorecki L., Korabecny J., Musilek K. et al.: Archives of Toxicology 2016, 90 (12), 2831. https://doi.org/10.1007/s00204-016-1827-3

[11] Carletti E., Colletier J.P., Dupeux F. et al.: Journal of Medicinal Chemistry 2010, 53 (10), 4002. https://doi.org/10.1021/jm901853b

[12] Hamblin J.: "What Does Sarin Do to People 2013?". https://www.theatlantic.com/health/archive/2013/05/ what-does-sarin-do-to-people/275577/ (access date 3008 2020).

[13] Worek F., Koller M., Thiermann H. et al.: Toxicology 2005, 214 (3), 182. https://doi.org/10.1016/j.tox.2005.06.012 
[14] Candiotti K.: Canadian Journal of Anesthesia/Journal canadien d'anesthésie 2017, 64 (10), 1059. https://doi.org/10.1007/s12630-017-0920-2

[15] Newmark J.: The Neurologist 2007, 13 (1), 20. https://doi.org/10.1097/01.nrl.0000252923.04894.53

[16] Kuca K., Korabecny J., Dolezal R. et al.: RSC Advances 2017, 7 (12), 7041. https://doi.org/10.1039/C6RA16499D

[17] Norrrahim M.N.F., Razak M.A.I.A., Shah N.A.A. et al.: RSC Advances 2020, 10 (8), 4465. https://doi.org/10.1039/C9RA08599H

[18] Holmes O., Phillips T.: “Kim Jong-nam killed by VX nerve agent, say Malaysian police", The Guardian 2017.

[19] Rodriguez-Llanes J.M., Guha-Sapir D., Schlüter B.S.: Conflict and Health 2018, 12 (1), 1. https://doi.org/10.1186/s13031-018-0150-4

[20] Dickinson E.T., Love J.S.: Journal of Emergency Medical Services 2017, 42 (9).

https://www.jems.com/2017/09/01/a-review-ofchemical-warfare-agents-and-treatment (access date 2910 2020).

[21] Alali K.T., Liu J., Aljebawi K. et al.: Journal of Alloys and Compounds 2019, 780, 680. https://doi.org/10.1016/j.jallcom.2018.11.317

[22] Lee J.S., Shin D.H., Jun J.: ACS Nano 2013, 7 (11), 10139. https://doi.org/10.1021/nn404353w

[23] Schroeder V., Savagatrup S., He M. et al.: Chemical Reviews 2018, 119 (1), 599. https://doi.org/10.1021/acs.chemrev.8b00340

[24] Spinelle L., Gerboles M., Kok G. et al.: Sensors 2017, 17 (7), 1520. https://doi.org/10.3390/s17071520

[25] Park J., Kim J., Kim K.: Nanoscale 2016, 8 (20), 10591. https://doi.org/10.1039/C6NR01468B

[26] Holdren S., Tsyshevsky R., Fears K. et al.: ACS Catalysis 2018, 9 (2), 902. https://doi.org/10.1021/acscatal.8b02999

[27] Agrawal M., Sava Gallis D.F., Greathouse J.A. et al.: The Journal of Physical Chemistry C 2018, 122 (45), 26061. https://doi.org/10.1021/acs.jpcc.8b08856

[28] Bartelt-Hunt S.L., Knappe D.R., Barlaz M.A.: Critical Reviews in Environmental Science and Technology 2008, 38 (2), 112. https://doi.org/10.1080/10643380701643650

[29] Mathieu O., Kulatilaka W.D., Petersen E.L.: Combustion and Flame 2018, 191, 320. https://doi.org/10.1016/j.combustflame.2018.01.020

[30] Shangguan Y.: "Intrinsic Properties of Poly(EtherB-Amide) (Pebax $\left.{ }^{\circledR} 1074\right)$ for Gas Permeation and Pervaporation", University of Waterloo, 2011.

[31] Delfino R.T., Ribeiro T.S., Figueroa-Villar J.D.: Journal of the Brazilian Chemical Society 2009, 20 (3), 407. http://dx.doi.org/10.1590/S0103-50532009000300003

[32] Trotochaud L., Head A.R., Büchner C. et al.: Surface Science 2019, 680, 75.

https://doi.org/10.1016/j.susc.2018.10.003
[33] Kuiper A.E.T., Van Bokhoven J.J.G.M., Medema J.: Journal of Catalysis 1976, 43 (1-3), 154. https://doi.org/10.1016/0021-9517(76)90302-X

[34] Powroźnik P., Grządziel L., Jakubik W. et al.: Sensors and Actuators B: Chemical 2018, 273, 771. https://doi.org/10.1016/j.snb.2018.06.101

[35] Kim T.I., Maity S.B., Bouffard J. et al.: Analytical Chemistry 2016, 88 (18), 9259. https://doi.org/10.1021/acs.analchem.6b02516

[36] Dagnaw F.W., Feng W., Song Q.H.: Sensors and Actuators B: Chemical 2020, 318, 127937. https://doi.org/10.1016/j.snb.2020.127937

[37] Aldahhak H., Powroznik P., Pander P. et al.: The Journal of Physical Chemistry C 2020, 124 (11), 6090. https://doi.org/10.1021/acs.jpcc.9b11116

[38] Li J., Lu Y., Ye Q. et al.: Electrochemical and Solid State Letters 2005, 8 (11), H100. https://doi.org/10.1149/1.2063289

[39] Kauffman D.R., Star A.: Analyst 2010, 135 (11), 2790. https://doi.org/10.1039/C0AN00262C

[40] Zhang T., Nix M.B., Yoo B.Y. et al.: Electroanalysis 2006, 18 (12), 1153. https://doi.org/10.1002/elan.200603527

[41] Johnson A.C., Staii C., Chen M. et al.: Semiconductor Science and Technology 2006, 21 (11), S17. https://doi.org/10.1088/0268-1242/21/11/S03

[42] Mangu R., Rajaputra S.V.P.: Nanotechnology 2011, 22 (21), 215502. https://doi.org/10.1088/0957-4484/22/21/215502

[43] Choi S.W., Kim J., Byun Y.T.: Sensors and Actuators B: Chemical 2017, 238, 1032. https://doi.org/10.1016/j.snb.2016.07.153

[44] Janudin N., Abdullah N., Wan Yunus W.M.Z. et al.: Journal of Nanotechnology 2018. https://doi.org/10.1155/2018/2107898

[45] Gong S., Wu D., Li Y. et al.: Carbon 2018, 137, 188. https://doi.org/10.1016/j.carbon.2018.05.029

[46] Abdulla S., Mathew T.L., Pullithadathil B.: Sensors and Actuators B: Chemical 2015, 221, 1523. https://doi.org/10.1016/j.snb.2015.08.002

[47] Rahman M.M., Hussein M.A., Alamry K.A. et al.: Nano-Structures \& Nano-Objects 2018, 15, 63. https://doi.org/10.1016/j.nanoso.2017.08.006

[48] Bagheri H., Hajian A., Rezaei M. et al.: Journal of Hazardous Materials 2017, 324, 762. https://doi.org/10.1016/j.jhazmat.2016.11.055

[49] Wang M.Q., Zhang Y., Bao S.J. et al.: Electrochimica Acta 2016, 190, 365. https://doi.org/10.1016/j.electacta.2015.12.199

[50] Sharma A.K., Mahajan A., Bedi R.K. et al.: Applied Surface Science 2018, 427, 202. https://doi.org/10.1016/j.apsusc.2017.08.040

[51] Ying Z., Jiang Y., Du X. et al.: Sensors and Actuators B: Chemical 2007, 125 (1), 167. https://doi.org/10.1016/j.snb.2007.02.002

[52] Kientz C.E.: Journal of Chromatography A 1998, 814 $(1-2), 1$. 
https://doi.org/10.1016/S0021-9673(98)00338-0

[53] Degenhardt-Langelaan C.E.A.M., Kientz C.E.: Journal of Chromatography A 1996, 723 (1), 210. https://doi.org/10.1016/0021-9673(95)00822-5

[54] Hooijschuur E.W.J., Kientz C.E., Udo A.: Journal of Chromatography A 2001, 928 (2), 187. https://doi.org/10.1016/S0021-9673(01)01133-5

[55] Hook G.L., Kimm G., Koch D. et al.: Journal of Chromatography A 2003, 992 (1-2), 1. https://doi.org/10.1016/S0021-9673(03)00278-4

[56] Eckenrode B.A.: Journal of the American Society for Mass Spectrometry 2001, 12 (6), 683. https://doi.org/10.1021/jasms.8b01632

[57] Vermillion W.D., Crenshaw M.D.: Journal of Chromatography A 1997, 770 (1-2), 253. https://doi.org/10.1016/S0021-9673(97)00160-X

[58] Juillet Y., Gibert E., Begos A. et al.: Analytical and Bioanalytical Chemistry 2005, 383 (5), 848. https://doi.org/10.1007/s00216-005-0064-z

[59] Wang J., Chatrathi M.P., Mulchandani A. et al.: Analytical Chemistry 2001, 73 (8), 1804. https://doi.org/10.1021/ac001424e

[60] Kubáň P., Seiman A., Makarõtševa N. et al.: Journal of Chromatography A 2011, 1218 (18), 2618. https://doi.org/10.1016/j.chroma.2011.03.006

[61] Bartlett P.N., Archer P.B.M., Ling-Chung S.K.: Sensors and Actuators 1989, 19 (2), 125. https://doi.org/10.1016/0250-6874(89)87065-9

[62] Petty M.C., Casalini R.: Engineering Science \& Education Journal 2001, 10 (3), 99. https://doi.org/10.1049/esej:20010304

[63] An K.H., Jeong S.Y., Hwang H.R. et al.: Advanced Materials 2004, 16 (12), 1005. https://doi.org/10.1002/adma.200306176

[64] Gaikwad S., Bodkhe G., Deshmukh M. et al.: Modern Physics Letters B 2015, 29 (06n07), 1540046. https://doi.org/10.1142/S0217984915400461

[65] Wang X., Ugur A., Goktas H. et al.: ACS Sensors 2016, $1(4), 374$. https://doi.org/10.1021/acssensors.5b00208

[66] Arif M.F., Kumar S., Gupta T.K. et al.: Composites Part A: Applied Science and Manufacturing 2018, 113, 141. https://doi.org/10.1016/j.compositesa.2018.07.021
[67] Fennell J.F., Hamaguchi H., Yoon B. et al.: Sensors 2017, 17 (5), 982. https://doi.org/10.3390/s17050982

[68] MacDiarmid A.G., Epstein A.J.: Synthetic Metals 1995, 69 (1-3), 85. https://doi.org/10.1016/0379-6779(94)02374-8

[69] Derycke V., Martel R., Appenzeller J. et al.: Applied Physics Letters 2002, 80 (15), 2773. https://doi.org/10.1063/1.1467702

[70] Ramesh S., Lee Y.J., Msolli S. et al.: RSC Advances 2017, 7 (80), 50912. https://doi.org/10.1039/C7RA09161C

[71] Powroznik P., Jakubik W., Stolarczyk A. et al.: Sensors 2020, 20 (2), 491. https://doi.org/10.3390/s20020491

[72] Pingel P., Arvind M., Kölln L.et al.: Advanced Electronic Materials 2016, 2 (10), 1600204. https://doi.org/10.1002/aelm.201600204

[73] Jin S., Xue G.: Macromolecules 1997, 30 (19), 5753. https://doi.org/10.1021/ma9606925

[74] Xu M., Lu D., Garsuch A. et al.: Journal of the Electrochemical Society 2012, 159 (12), A2130. https://doi.org/10.1149/2.077212jes

[75] Wang F., Gu H., Swager T.M.: Journal of the American Chemical Society 2008, 130 (16), 5392. https://doi.org/10.1021/ja710795k

[76] Zhang R.Q., Wang L.B., Bai R.X. et al.: Composites Part B: Engineering 2019, 173, 106894. https://doi.org/10.1016/j.compositesb.2019.05.105

[77] Chang C.P., Yuan C.L.: Journal of Materials Science 2009, 44 (20), 5485. https://doi.org/10.1007/s10853-009-3766-3

[78] Yoo R., Kim J., Song M.J. et al.: Sensors and Actuators B: Chemical 2015, 209, 444. https://doi.org/10.1016/j.snb.2014.11.137

[79] Kumar D., Jha P., Chouksey A. et al.: Materials Chemistry and Physics 2016, 181, 487. https://doi.org/10.1016/j.matchemphys.2016.06.085

[80] Lai Y.T., Kuo J.C., Yang Y.J.: Applied Physics Letters 2013, 102 (19), 191912. https://doi.org/10.1063/1.4804297

[81] Yuan C.L., Chang C.P.: Chung Cheng Institute of Technology 2009, 38, 147. 